\title{
Mudanças feições morfológicas no baixo curso do rio Cabaçal, afluente da margem esquerda do rio Paraguai, Mato Grosso
}

\author{
Changes morphological fections in the low course of the Cabaçal river, affecting the left margin of \\ the Paraguai river, Mato Grosso
}

Cambios en las características morfológicas en el curso inferior del río Cabaçal, afluente de la margen izquierda del río Paraguai, Mato Grosso

Recebido: 03/09/2021 | Revisado: 10/09/2021 | Aceito: 13/09/2021 | Publicado: 14/09/2021

\author{
Cristiane da Silva Lima \\ ORCID: https://orcid.org/0000-0001-6435-2572 \\ Universidade do Estado de Mato Grosso, Brasil \\ E-mail: Cristiane-silva89@hotmail.com \\ Thales Ernildo de Lima \\ ORCID: https://orcid.org/0000-0002-8494-0192 \\ Universidade do Estado de Mato Grosso, Brasil \\ E-mail: lima.thales@outlook.com \\ Celia Alves de Souza \\ ORCID: https://orcid.org/0000-0002-9068-9328 \\ Universidade do Estado de Mato Grosso, Brasil \\ E-mail: celiaalvesgeo@globo.com \\ Maria Elia dos Santos Vieira \\ ORCID: https://orcid.org/0000-0002-3413-8556 \\ Faculdades Cearenses, Brasil \\ E-mail: maria.elia@gmail.com
}

\begin{abstract}
Resumo
Os estudos sobre as mudanças das feições morfológicas são importantes para entender o funcionamento de um sistema fluvial. A presente pesquisa teve como objetivo avaliar a evolução das feições morfológicas, a migração lateral no baixo curso do rio Cabaçal, Mato Grosso. Para caracterizar os elementos ambientais, utilizou-se a base cartográfica do projeto RADAMBRASIL (1982). Para analisar as alterações das feições morfológicas no baixo curso do rio Cabaçal, usaram-se as imagens LANDSAT dos anos de 1984 e 2018; para confecção dos mapas temporais, as ferramentas o software ArcGis 10.1 e do software Spring 5.2. No decorrer de 34 anos, aumentou o número de baías e lagoas, intensificação do processo de sedimentação com o surgimento e barras de sedimentos. As feições morfológicas registradas em 1984 nos compartimentos 1, 11 e 111 foram 57 baías, 345 lagoas e 13 barras de sedimentos; em 2018, computaram-se 61 baías, 502 lagoas, 50 barras de sedimentos e sete ilhas fluviais. A pesquisa apresentou as mudanças espaciais, gerando informações relevantes sobre o baixo curso do Cabaçal, podendo subsidiar medidas de recuperação e preservação da bacia.
\end{abstract}

Palavras-chave: Rio Cabaçal; Feições morfológicas; Mudanças espaciais.

\begin{abstract}
Studies on changes in morphological features are important to understand the functioning of a river system. This research aimed to evaluate the evolution of the morphological features, the lateral migration in the lower course of the Cabaçal river, Mato Grosso. To characterize the environmental elements, the cartographic basis of the RADAMBRASIL project (1982) was used. To analyze the alterations of the morphological features in the low course of the Cabaçal river, LANDSAT images from the years 1984 and 2018 were used. For making the temporal maps, the ArcGis 10.1 and Spring 5.2 software were used. Over the course of 34 years, the number of bays and lagoons has increased, intensification of the sedimentation process with the appearance and sediment bars. The morphological features recorded in 1984 in compartments 1, 11 and 111 were 57 bays, 345 lagoons and 13 sediment bars; in 2018, 61 bays, 502 lagoons, 50 sediment bars and seven river islands were computed. The research presented the spatial changes generating relevant information about the low course of Cabaçal, being able to subsidize measures of recovery and preservation of the basin.
\end{abstract}

Keywords: Cabaçal River; Morphological; Spatial changes. 


\begin{abstract}
Resumen
Los estudios sobre cambios en las características morfológicas son importantes para comprender el funcionamiento de un sistema fluvial. Esta investigación tuvo como objetivo evaluar la evolución de características morfológicas, la migración lateral en el curso inferior del río Cabaçal, Mato Grosso. Para caracterizar los elementos ambientales se utilizó la base cartográfica del proyecto RADAMBRASIL (1982). Para analizar los cambios en los rasgos morfológicos en el curso bajo del río Cabaçal, se utilizaron imágenes LANDSAT de los años 1984 y 2018; para hacer los mapas temporales, el software ArcGis 10.1 y las herramientas de software Spring 5.2. A lo largo de 34 años, el número de bahías y lagos aumentó, intensificando el proceso de sedimentación con la aparición de barras de sedimentos. Las características morfológicas registradas en 1984 en los compartimentos 1, 11 y 111 fueron 57 bahías, 345 lagos y 13 barras de sedimentos; en 2018, se calcularon 61 bahías, 502 lagos, 50 barras de sedimentos y siete islas fluviales. La investigación presentó los cambios espaciales, generando información relevante sobre el curso bajo del Cabaçal, que podría apoyar medidas para la recuperación y preservación de la cuenca.

Palabras clave: Rio Cabaçal; Características morfológicas; Cambios espaciales.
\end{abstract}

\title{
1. Introdução
}

O presente estudo foi realizado no baixo curso da bacia hidrográfica do rio Cabaçal, no estado do Mato Grosso, sabendo-se que bacia hidrográfica é uma unidade geomorfológica que interage com os fatores físicos, biológicos, econômicos e sociais (Guerra \& Cunha, 2004). Avelino (2006) e Santos (2011) destacam que a bacia hidrográfica supracitada possui área de $6.042 \mathrm{~km}^{2}$ e suas nascentes estão na Chapada dos Parecis, percorrendo um trecho de depressão no alto e médio curso. No baixo curso, envolve área de planície, próxima da confluência com rio Paraguai. Seus principais afluentes são rio Branco, rio Vermelho e rio dos Bugres.

Souza (2004) destaca que o rio Paraguai é considerado um dos mais importantes do Brasil, seus afluentes margeiam vasta planície e pantanal mato-grossense, transportando água e sedimentos que contribuem com a dinâmica das feições morfológicas no corredor fluvial, planície de inundação e nas características hidrológicas do pantanal.

A migração lateral nos canais fluviais está, intimamente, associada às mudanças no curso dos rios e desenvolvimento da planície de inundação. A compreensão de seus processos é, portanto, fundamental para o entendimento sobre o desenvolvimento de feições fluviais (Hooke, 1979).

Souza e Sousa (2014) dizem que as mudanças que acontecem na calha do rio estão relacionadas com a própria dinâmica do corredor fluvial, associadas com a variação na precipitação e dinâmica no regime hidrológico, declividade do terreno e característica do solo. Tais fatores contribuem com a dinâmica de erosão, transporte e deposição de sedimentos; porém, a ação antrópica acelera as mudanças.

Stevaux e Latrubesse (2017) relatam que há uma diferenciação na morfologia de canais meandrantes, que podem ser regulares com homogeneidade, ou irregulares, quando apresentam alterações nos tamanhos e formas, e tortuosos, quando há mudança na morfologia.

Castro, Decampos e Zancopé (2014) estudaram a migração do canal na planície fluvial do rio Claro, na bacia do rio Araguaia, em Goiás, no intervalo de 24 anos de (1988 a 2012) e relataram que o baixo curso do rio Claro está sofrendo uma acelerada mobilidade do canal fluvial, identificada por análise temporal das imagens de satélite. Destacam, ainda, que a mobilidade do canal acontece a partir da combinação variada de processos que influenciam a migração do canal.

Vários pesquisadores realizaram estudos sobre evolução de feição morfológica, quais sejam: Goswami, Sarma e Patgiri (1999), em Assan (Índia), monitorando a feição morfológica no rio Subanssiri. No Brasil, destacam-se Fernandez (1990), com estudo sobre mudanças no canal fluvial do rio Paraná; Souza (1998) sobre a dinâmica do córrego Piraputanga; Souza e Cunha (2007), que discutiram evolução das margens do rio Paraguai, entre a cidade de Cáceres e a Estação Ecológica da Taimã, Mato Grosso; Silva et. al., (2013) discutiram a evolução de feição no rio Paraguai. Pesquisadores, como Brigante e Espíndola (2003), Souza (2004), Bayer e Carvalho (2008), Leandro e Souza (2012) e Silva et al., (2014) registraram estudos de sedimentação em canais fluviais. Quanto a análises sobre migração lateral do rio Paraguai, ganham destaque as pesquisas de 
Souza e Cunha (2007), Silva e Farias (2007), Justiniano (2010), Silva (2011), Leandro \& Souza (2012) e Leandro et al., (2012).

Este estudo objetivou avaliar a evolução das feições morfológicas e a migração lateral no baixo curso do rio Cabaçal, afluente a margem esquerda o rio Paraguai.

\section{Metodologia}

A área de estudo corresponde ao baixo curso do rio Cabaçal, localizada entre as coordenadas geográficas $15^{\circ} 28^{\prime} 08^{\prime \prime}$ a $15^{\circ} 46^{\prime} 24^{\prime \prime}$ 'S Latitude e $57^{\circ} 53^{\prime} 35^{\prime \prime}$ a $57^{\circ} 48^{\prime} 8^{\prime}$ ' W Longitude. A extensão longitudinal do rio no segmento corresponde a $65,925 \mathrm{~km}$, com área correspondente ao baixo curso da bacia hidrográfica de 711,74 km², que abrange parte dos municípios de Mirassol do Oeste, Curvelândia, Lambari do Oeste, e Cáceres (Figura 1).

Os climas tropicais de Mato Grosso apresentam uma variação climática devido à grande extensão territorial que o estado possui $(903.357,91 \mathrm{~km})$. A dimensão do território propicia características importantes como oscilação e repetição na dinâmica estacional bem diferenciada, alternadamente quente e úmido. O balanço hídrico destaca-se pela estação de seca (oito meses), que inicia em abril e finaliza, aproximadamente, nos primeiros quinze dias de novembro. A deficiência hídrica nesse período de seca corresponde à diminuição da precipitação média entre 300 a 350 mm, enquanto que, de janeiro a março, há um excesso de 300 a $400 \mathrm{~mm}$, que corresponde ao período chuvoso (SEPLAG, 2011). 
Figura 1: Localização a área de baixo curso da bacia hidrográfica do rio Cabaçal.
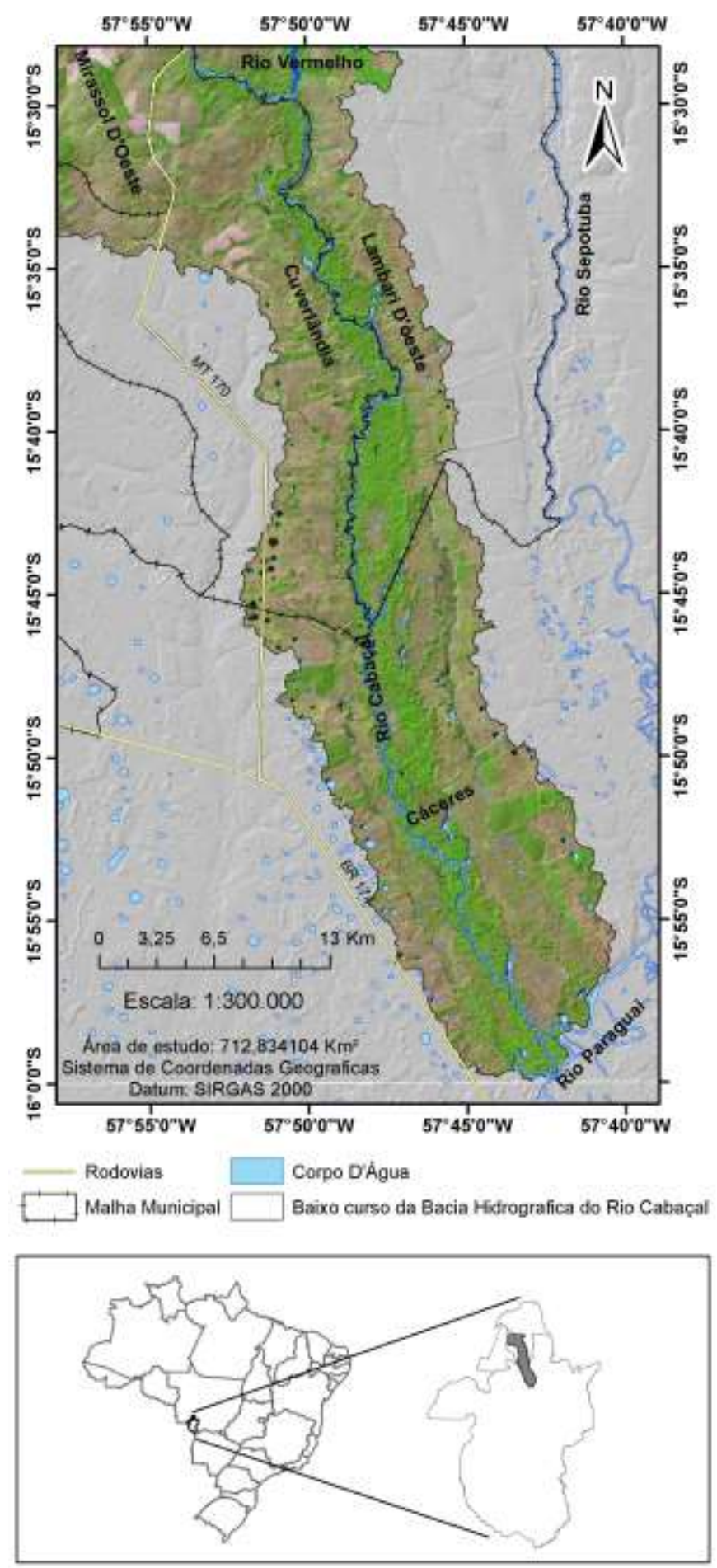

Fonte: Autores.

O baixo curso do Cabaçal apresenta o clima Tropical Continental Alternadamente Úmido e Seco das chapadas. Nas depressões de Mato Grosso, predomina o (lllE1) Mesotérmico Subúmido das Depressões e Pantanais. Com altitudes que variam de 100 a $200 \mathrm{~m}$, a temperatura apresenta variação máxima entre $32.3^{\circ} \mathrm{C}$ a $32.9^{\circ} \mathrm{C}$ e mínima entre $20.0^{\circ} \mathrm{C}$ a $29.9^{\circ} \mathrm{C}$. A pluviosidade anual nessa unidade climática é equivalente a 1.300mm - 1.400mm (SEPLAG, 2011).

Os últimos registros das estações pluviométricas de Cáceres e região, dados secundários extraídos da plataforma hidroweb da Agência Nacional das Águas (ANA), permitiram gerar informações relacionadas à precipitação média anual entre 
os anos de 1969 e 2006 na área de estudo (Figura 2).

Figura 2: Precipitação total anual do baixo curso do rio Cabaçal.

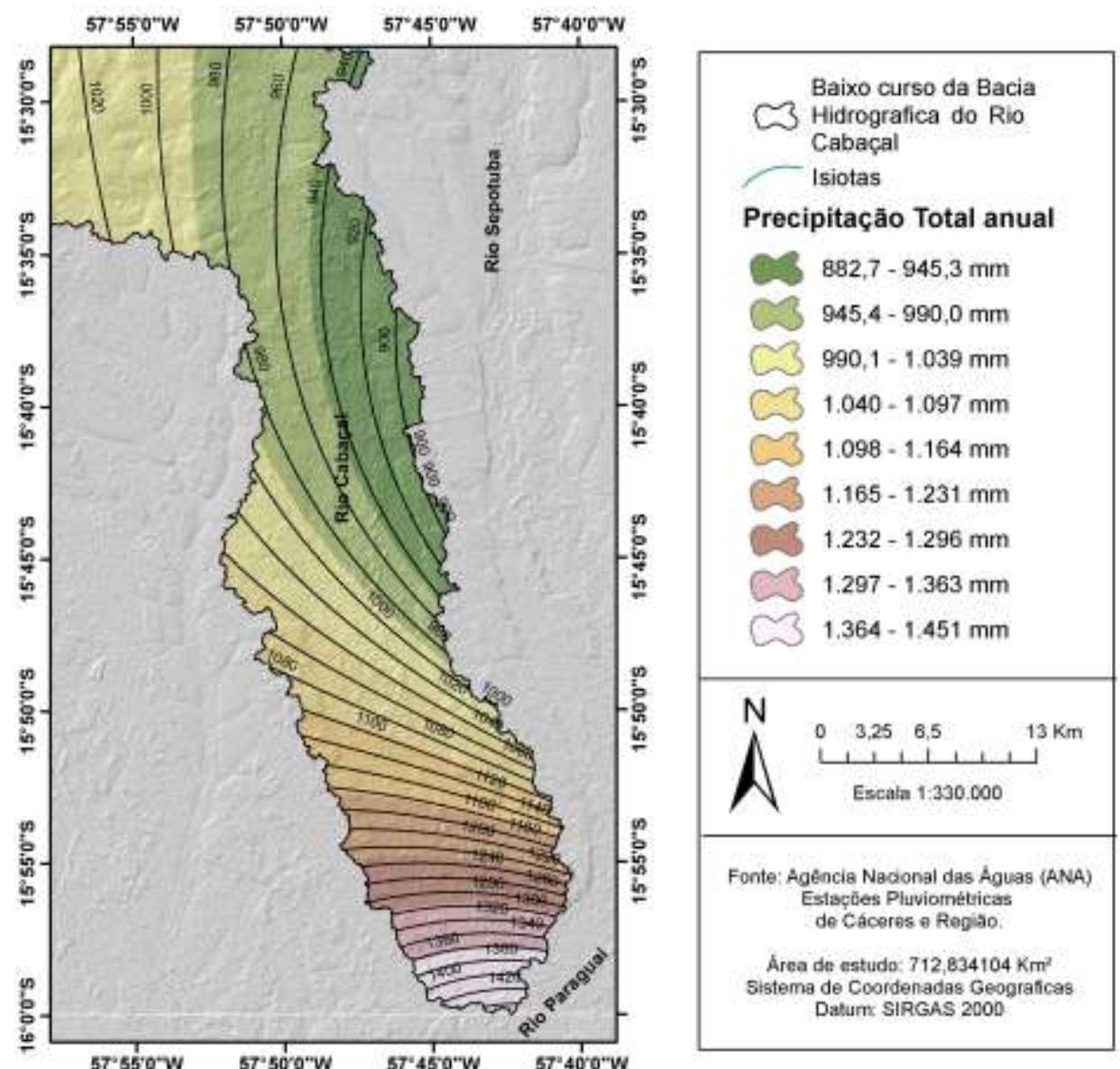

Fonte: Autores.

Os dados apresentados no mapa mostram níveis de precipitação de 882,7 mm a 943,3 mm a leste, alcançando níveis elevados de precipitação $(1.364 \mathrm{~mm}$ a $1.451 \mathrm{~mm})$ ao sul, onde o rio Cabaçal faz a confluência com rio Paraguai. Observa-se que, a norte, os níveis de precipitação variam entre $882,7 \mathrm{~mm}$ a $1.093 \mathrm{~mm}$.

Os aspectos geológicos de uma bacia hidrográfica têm sua importância por determinar os fluxos de drenagem (divisores de águas), bem como o entendimento sobre as partículas sedimentares transportadas pelo fluxo hídrico da cabeceira até áreas diversas a jusante. Souza $(2004 ; 2012)$ afirma que a compreensão sobre a estrutura geológica surge como subsídio a entender o tipo de sedimentos que advém de processos erosivos, os quais vão sendo transportados e depositados ao longo do curso no canal fluvial. Na área de estudo, registrou-se a ocorrência de Formação Pantanal (57,07\%), Aluviões atuais (40,48\%) e Aluviões indiferenciadas ou antigas (2,45\%) (Figura 3).

Almeida (1964) discorre que os depósitos da Formação Pantanal são pouco espessos, com a composição arenoargilosos e síltico-argilosos, com granulometria predominantemente fina ou muito fina, ocorrendo também areias médias a conglomeráticos. Os grãos de quartzo são subarredondados e arredondados, as superfícies polidas com intercalações de níveis argilosos, tendo a fração cascalho, o resultado da movimentação ou dinâmica atual dos rios.

As aluviões indiferenciadas ou antigas são encontradas em relevos planos e pouco dissecados; são depósitos de terraços em planície aluvial e incluem-se também canais abandonados ou colmatados. É uma unidade que se constitui 
litologicamente por depósitos pouco espessos e é composta por areia, silte, argila e cascalho. Esses depósitos apresentaram dinâmica com comportamento em seus agentes deposicionais e foram relacionados com balanço da oscilação climática ou fenômeno tectônico (Brasil, 1982).

As aluviões atuais correspondem aos materiais inconsolidados que se encontram em deposição nos terraços e nas planícies fluviais no baixo curso da bacia hidrográfica do córrego Cachoeirinha próximo à confluência com o rio Paraguai. A origem das aluviões atuais relaciona-se à dinâmica dos períodos de cheia do rio Cabaçal, quando o rio transborda águas e sedimentos, depositando-os na planície de inundação (BAP, 1997).

Figura 3: Ocorrência geológica no baixo curso da bacia hidrográfica do rio Cabaçal.

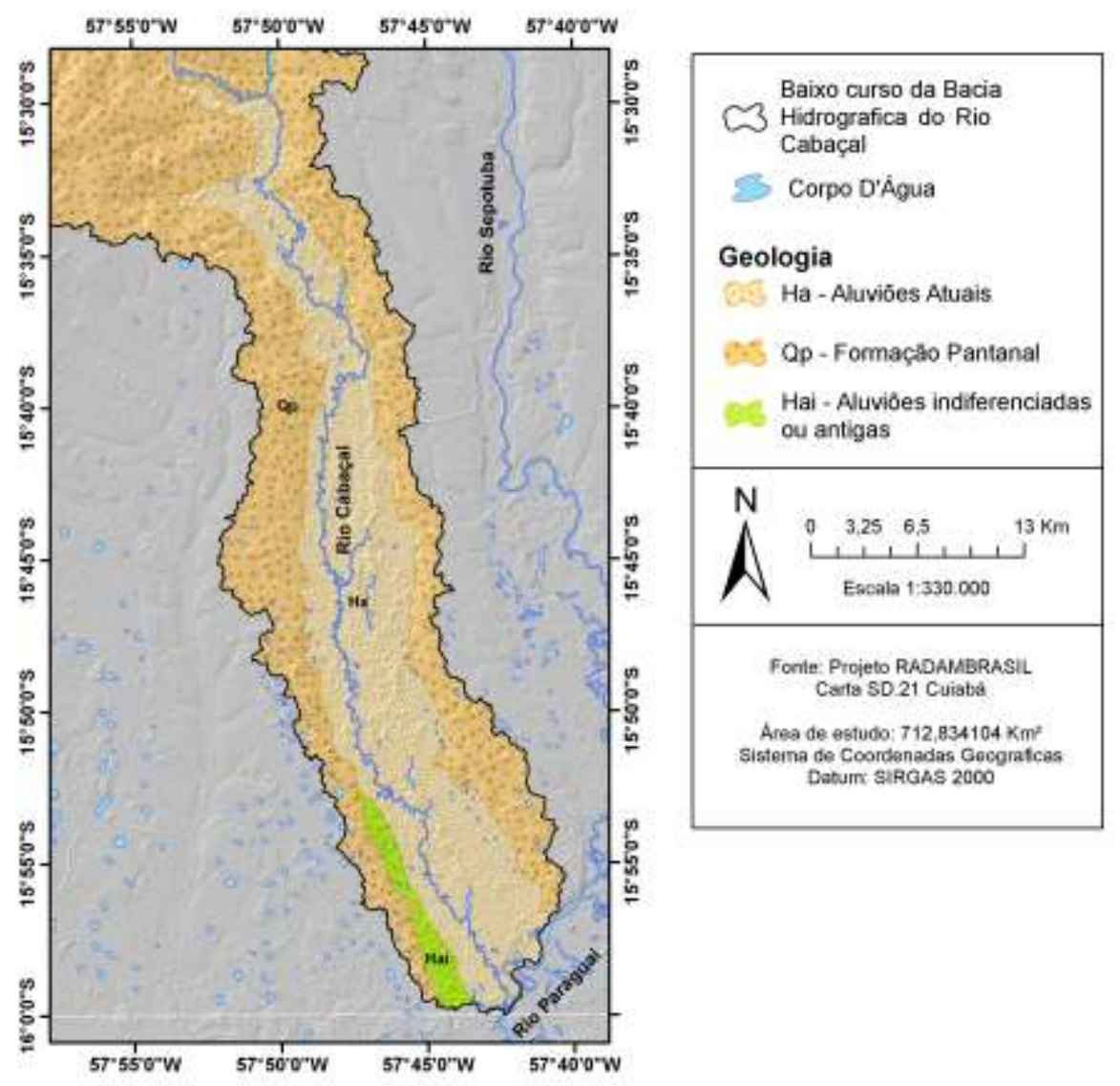

Fonte: Compilado/adaptado base vetorial (Brasil, 1982). Organizado pelos autores.

No baixo curso, o rio Cabaçal possui duas unidades geomorfológicas: a Depressão do Alto Paraguai, com área de $423,35 \mathrm{~km}^{2} \mathrm{e}$ a planície do rio Cabaçal $\left(240,74 \mathrm{~km}^{2}\right)$, com altitudes baixas de 150 a 300 metros (Figura 4).

A Depressão do Alto Paraguai é uma unidade geomorfológica originada por resquícios de acumulação marinha, caracterizada por apresentar relevos baixos e tem como característica área rebaixadas e drenadas pelos tributários (Brasil, 1982). Para Ross E Santos (1982), a subunidade de relevo compreende uma extensa área drenada pelo rio Cabaçal. Envolve uma superfície de relevo pouco dissecado com pequeno caimento topográfico de norte a sul, apresentando característica rampeada em sua seção oeste com altimetria oscilante entre 120 e 300 metros. 
Figura 4: Unidades geomorfológicas no baixo da bacia hidrográfica do rio Cabaçal.

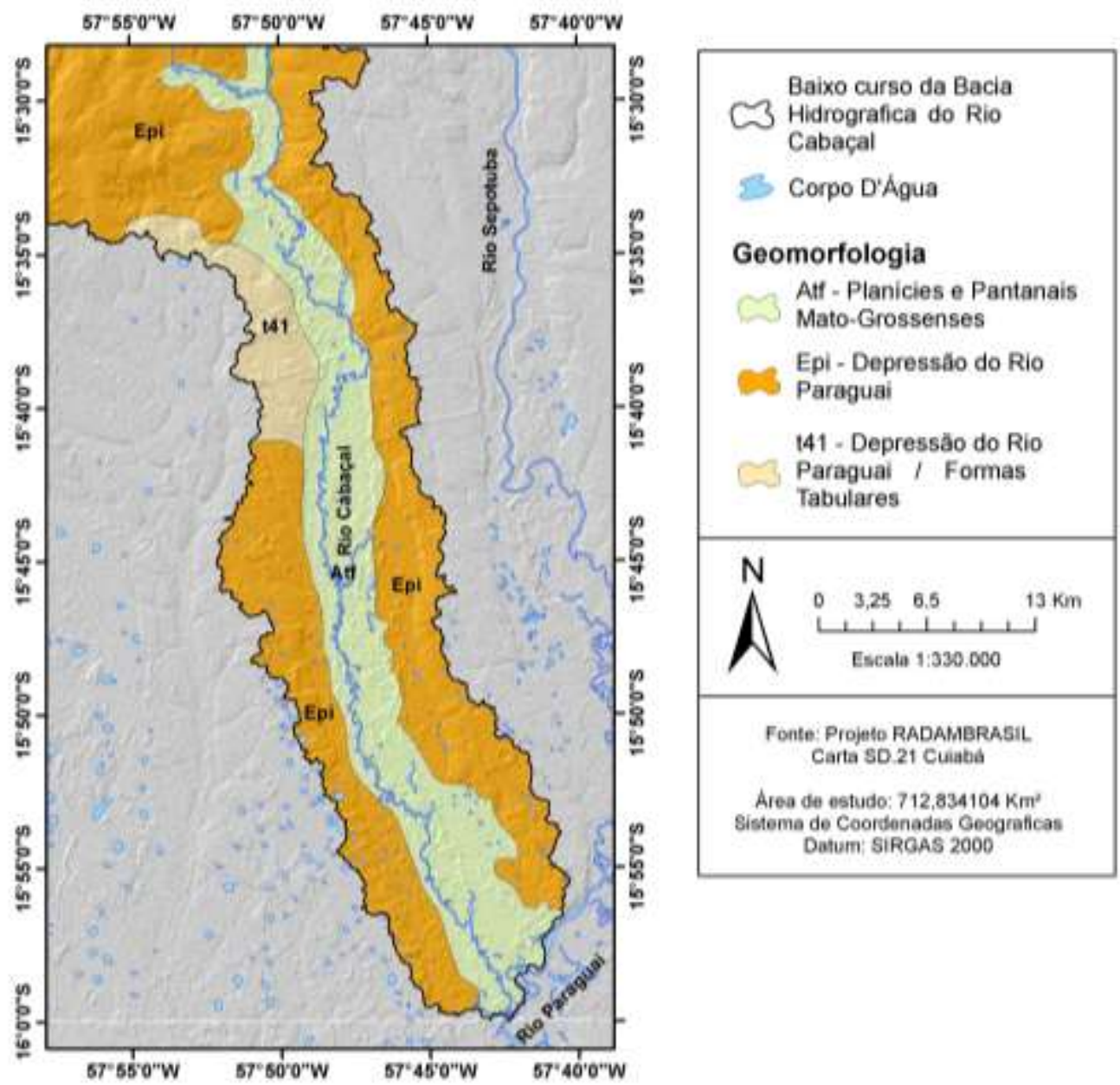

Fonte: Compilado/adaptado base vetorial (Brasil, 1982). Organizado pelos autores.

As planícies e pantanais mato-grossenses encontram-se entre 80 a 150 metros de altitude, em relação ao nível do mar, constituídas por acumulação de depósitos de sedimentos carregados através do rio, que possui nascentes nos planaltos, serras e depressões que o circundam. As configurações morfológicas da planície estão associadas ao padrão de canal (meandrante), sazonalidade (estiagem e cheias), à baixa declividade do terreno e à carga de sedimentos que são transportadas pelo rio principal e o uso da terra na bacia. Os gradientes são baixos nas áreas de planície, alterando constantemente com formação de feições morfológicas (Souza, 2004).

As classes de solos, presente no baixo curso da bacia hidrográfica, segundo dados retirados de RADAMBRASIL: levantamentos dos recursos naturais (Brasil, 1982), são os Neossolos Quartzarênicos órtico típico, com área de 130,09 km², Latossolo Vermelho Amarelo Distrófico Típico, com área de 309,62 km² e Gleissolo Haplico Tb Eutrofico Típico, cobrindo uma área de 272,02 km² (Figura 5). 
Figura 5: Solos da área de estudo.

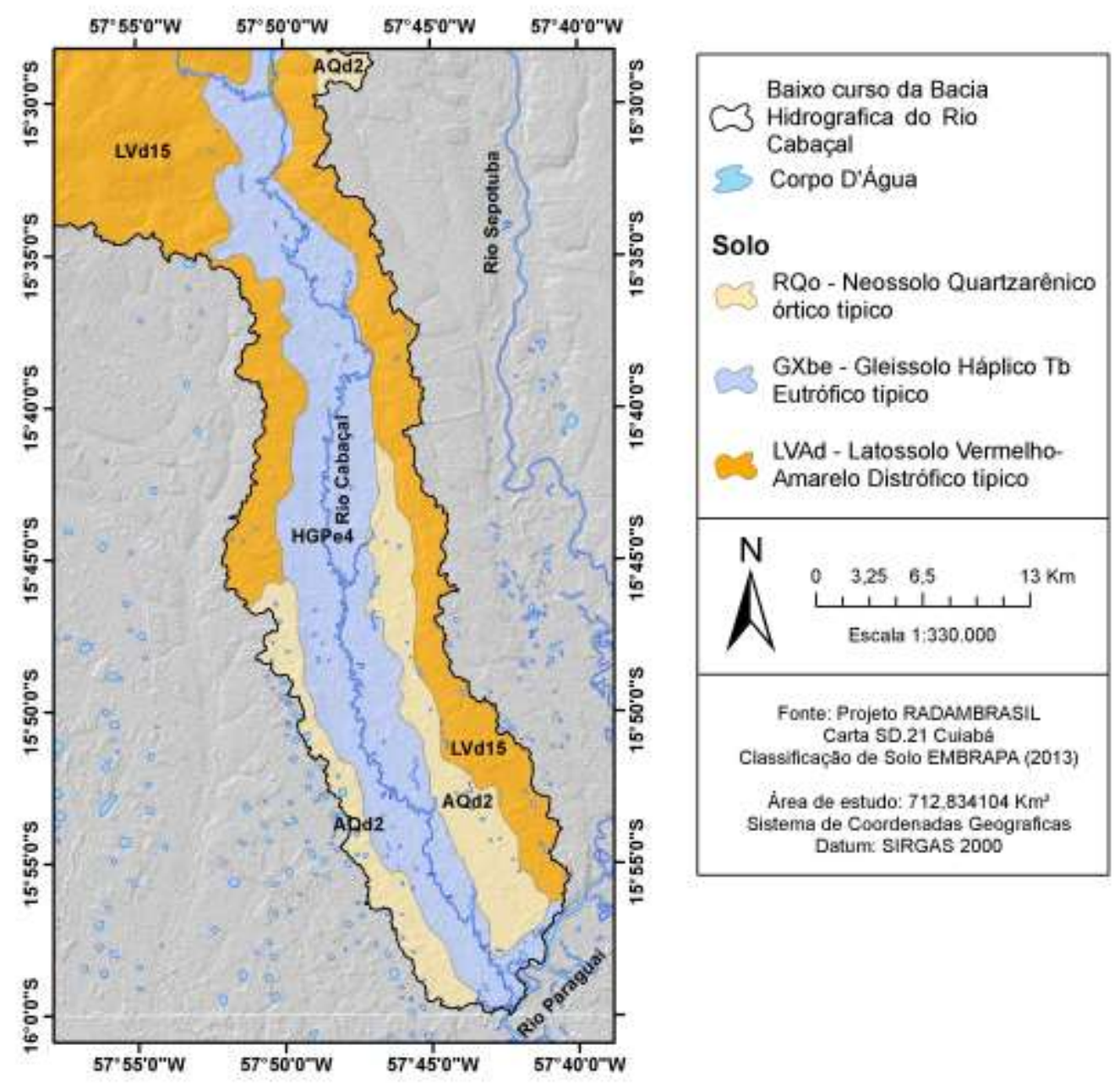

Fonte: Compilado/adaptado base vetorial (Brasil, 1982). Organizado pelos autores.

Os Neossolos Quartzarênicos correspondem a 18,28\% dos solos da área de estudo, encontrados em três manchas. Suas características físicas aliadas ao uso sem adotar as técnicas corretas de manejo potencializam o surgimento de processos erosivos que vão desde pequenos sulcos até mesmo grandes voçorocas.

Os Neossolos são poucos evoluídos, não possuem horizonte B diagnóstico. Praticamente não se vê diferenciação entre os horizontes, com individualização do horizonte A, seguido dos horizontes C ou R. Os Quartzarênicos são solos arenosos (Batista, Paiva \& Marcolino, 2014).

O Latossolo Vermelho Amarelo Distrófico Típico está presente em 43,50\% da área de estudo. Os Latossolos em geral apresentam horizonte subsuperficial uniforme em cor, textura e estrutura (horizonte B Latossólico). São profundos, geralmente pobres, ocupando as superfícies mais velhas e estáveis da paisagem. A intensa intemperização dos constituintes minerais ocasiona maior concentração relativa de argilo-minerais resistente. Possuem textura variável, média a muito argilosa, porosos, macios e permeáveis, pequena diferença no teor de argila em profundidade e são de baixa fertilidade natural (Batista, Paiva e Marcolino, 2014).

O Gleissolo Háplico Tb Eutrófico Típico está presente em 38,16\% da área de estudo, é caracterizado por apresentar forte gleização em virtude do regime de umidade redutor que se forma nos meios anaeróbicos originados de encharcamentos periódicos ou constantes. Para Oliveira, Amaral Filho e Vieira (1982), o Gleissolo Háplico Tb Eutrófico é um solo profundo, 
mal drenado, de baixa permeabilidade com características físicas e químicas muito variadas, devido à natureza do material de origem, como também a distância do regime hídrico dessas áreas.

\section{Procedimentos metodológicos}

Mapeamento

Para elaboração do mapa de localização da área de estudo, foi utilizada a imagem do satélite LANDSAT 8 OLI de 2017, com resolução espacial de 30 metros, sobre os parâmetros de órbita e ponto 227/071 com zero por cento de cobertura de nuvens. Esses dados foram obtidos gratuitamente pela plataforma Catálogo de Imagens - DGI-INPE, disponibilizado no site (www.dgi.inpe.br/catalogo/) do Instituto Nacional de Pesquisas Espaciais.

O mapeamento dos elementos ambientais foi executado com a utilização da base cartográfica do projeto RADAMBRASIL, realizado em 1982, com a participação de vários pesquisadores nacionais bem como do exército brasileiro. Importadas as cartas para o software ArcGis 10.1 no formato *.jpg e georreferenciado-as pelas coordenadas já contidas na carta, foi efetuado processo de vetorização analógico para serem posteriormente definidas conforme o relatório do projeto e calculada da área e porcentagem de cada elemento mapeado contido na área de estudo.

Para analisar as alterações das feições morfológicas no baixo curso do rio Cabaçal, foram selecionadas imagens de agosto do LANDSAT-5 TM para o ano de 1984. O mapa de 2018 utilizou imagem de agosto do LANDSAT-8 OLI, identificando a dinâmica que ocorreu no período de 34 anos e, para tanto, foram confeccionados três mapas temáticos do baixo curso para todos os anos 1984 e 2018. Cada mapa corresponde a um compartimento (1, ll e ll1), que está na escala de 1:150.000, para melhor representar espacialmente a dinâmica das feições morfológicas a serem classificadas. Usaram-se as ferramentas do software ArcGis 10.1 e do software Spring 5.2 para confecção dos mapas temporais. As informações obtidas foram confirmadas nas atividades de campo.

A área das classes diversas (feições morfológicas, elementos ambientais, declividade, etc.) quantificadas foram calculadas no sofware ArcGis 10.1 pela função Calculate Goemetry. Do mesmo modo, o layout e exportação do produto final (mapa temático) foi gerado pelo sofware ArcGis 10.1.

A representação pluviométrica anual na área de estudo foi compreendida e resultante por meio dos dados secundários obtidos pela plataforma hidroweb disponível no site da ANA (Agência Nacional das Águas), de onde foram extraídos os índices anuais das seguintes estações: Barranco Vermelho (01657006), Cáceres (01657000), Cáceres (DNPVN) (01657003), Conceição - Poconé (01657005), Descalvados (01657002), Destacamento da Corixa (01658000), Flechas (01657004), Goiabeira (01557002), Porto Esperidião (01558003), em uma série temporal de 1969 a 2006. O objetivo foi o de criar interpolação de dados com as variações pluviométricas, bem como as isoietas, sendo que essa série temporal se justifica porque, para a interpolação de dados, há necessidade de vários pontos distribuídos no espaço. Cabe ressalva que todas essas estações se encontram na atualidade desativadas e que esses anos foram o do último registro de coleta.

\section{Resultados e Discussão}

\subsection{Alterações nas feições morfológicas}

Os resultados mostram as mudanças espaço/temporal nas feições morfológicas (surgimento ou desaparecimento, redução ou aumento de dimensão de lagoas, baías, barras de sedimentos, ilhas fluviais) no baixo curso da bacia em três compartimentos. Souza (2004), ao estudar a dinâmica das feições no rio Paraguai, destacou que o canal fluvial apresenta uma intensa dinâmica, marcado por um processo de erosão acelerada. Esses processos influenciam a ligação direta de algumas feições, como a ligação de baías e braços com o canal principal, passando a transferir o fluxo do canal principal para o canal secundário. 
No compartimento 1, em 1984, constatou-se a existência de 18 baías, 67 lagoas e 10 barras de sedimentos, não sendo registrada a presença de ilhas fluviais. Em 2018, foram observadas feições remanescentes, perfazendo quatro baías, 26 lagoas e uma barra de sedimentos. Verificou-se também o surgimento de novas feições, sendo 21 baías, 108 lagoas, 10 barras de sedimentos e de cinco ilhas fluviais (antes não existentes) com áreas que variaram de 0,013 km² a 3,518 km². A formação das ilhas maiores (IL1 e IL2) ocorreu devido à junção de lagoas, baías, por isso compondo um novo canal. O aparecimento das ilhas menores (IL3, IL4 e IL5) está associado ao rompimento ao colo do meandro e acumulação de sedimentos. A área total das ilhas é de $6,996 \mathrm{~km}^{2}$ (Tabela 1; Figuras 6 e 7).

Tabela 1: Feições morfológicas mapeadas em 1984 e 2018, no baixo curso do rio Cabaçal (Compartimento I).

\begin{tabular}{|c|c|c|c|c|}
\hline \multirow{2}{*}{ Compartimentos } & \multirow{2}{*}{ Feições morfológicas } & \multirow{2}{*}{1984} & \multicolumn{2}{|c|}{2018} \\
\hline & & & Remanescente & Novas \\
\hline \multirow{4}{*}{ I } & Baías & 18 & 4 & 21 \\
\hline & Lagoas & 67 & 26 & 108 \\
\hline & Barras de sedimentos & 10 & 1 & 10 \\
\hline & Ilhas & - & - & 5 \\
\hline \multirow{4}{*}{ II } & Baías & 9 & 4 & 13 \\
\hline & Lagoas & 89 & 28 & 134 \\
\hline & Barras de sedimentos & 1 & - & 16 \\
\hline & Ilhas & - & - & 2 \\
\hline \multirow{4}{*}{ III } & Baías & 30 & 6 & 13 \\
\hline & Lagoas & 189 & 68 & 138 \\
\hline & Barras de sedimentos & 2 & - & 23 \\
\hline & Ilhas & - & - & 3 \\
\hline
\end{tabular}

Fonte: Autores. 
Research, Society and Development, v. 10, n. 12, e109101220226, 2021

(CC BY 4.0) | ISSN 2525-3409 | DOI: http://dx.doi.org/10.33448/rsd-v10i12.20226

Figura 6 Feições morfológicas 1984 no compartimento I.

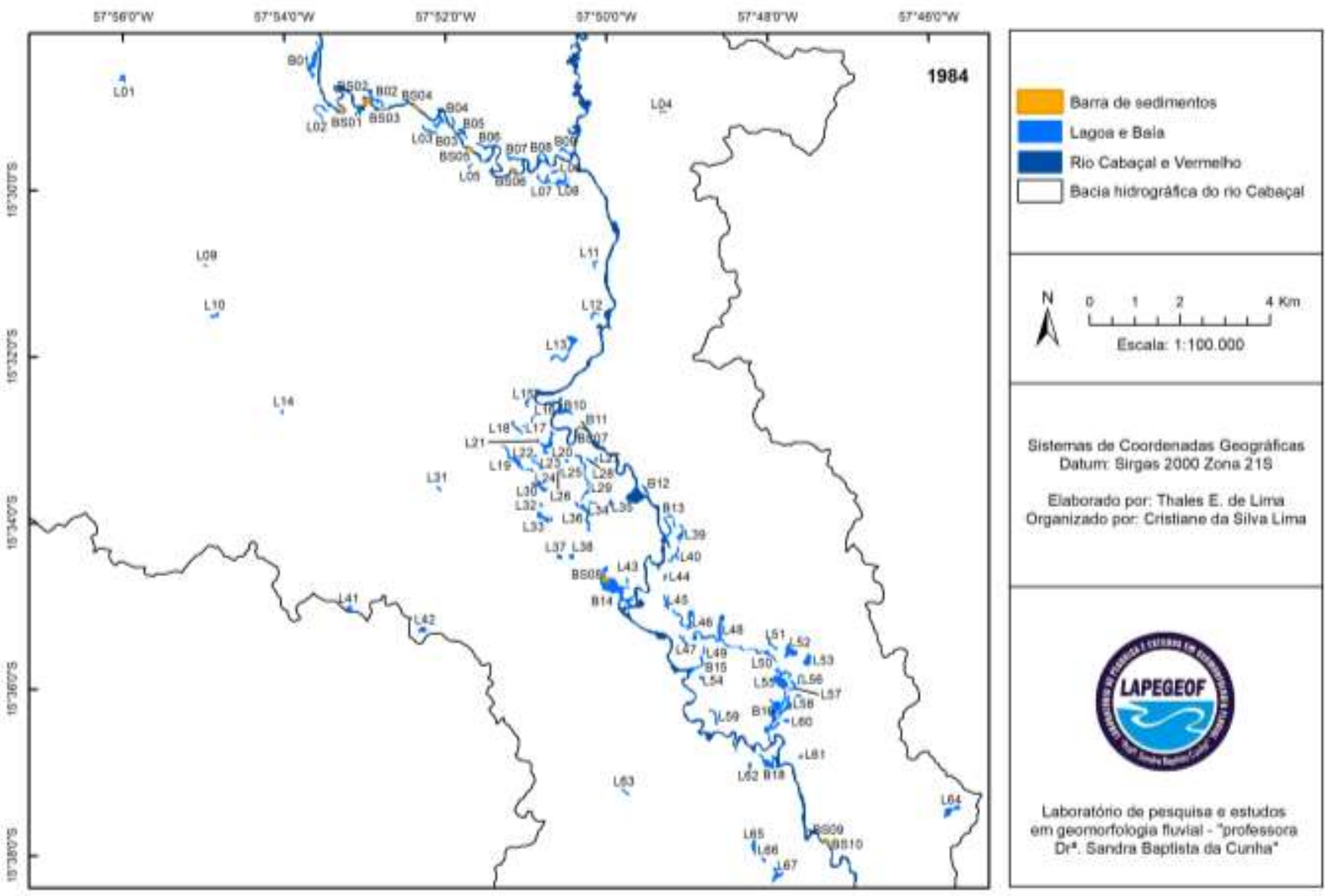

Fonte: Autores. 
Figura 7: Feições morfológicas 2018 (compartimento I).

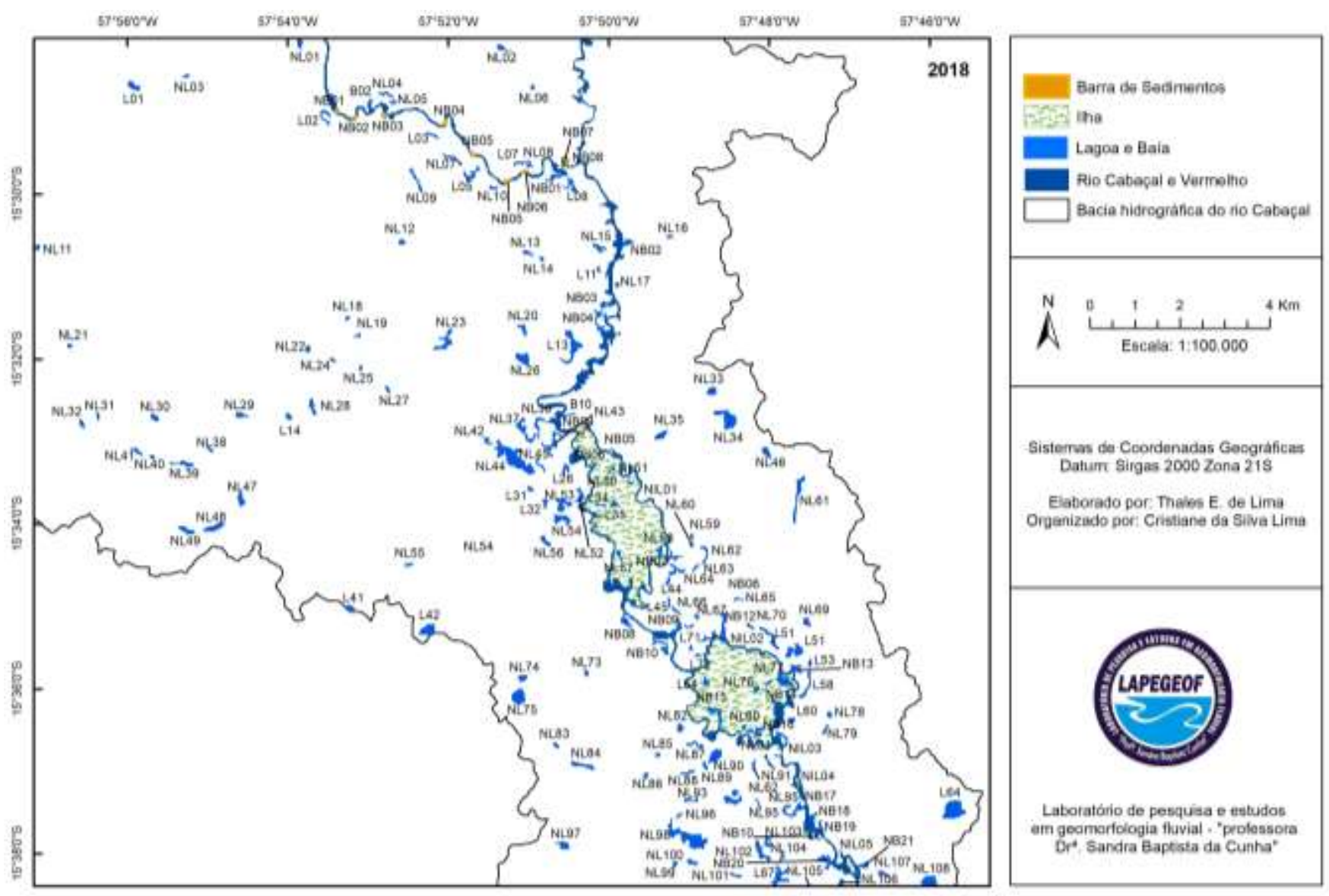

Fonte: Autores.

No compartimento II, em 1984, registrou-se a presença de nove baías, 89 lagoas e uma barra de sedimentos. Em 2018, foram detectadas quatro baías e 28 lagoas remanescentes. Houve o surgimento novas feições: 13 baías, 134 lagoas, 16 barras de sedimentos e duas ilhas fluviais; a ilha IL1, com área de $0,55 \mathrm{~km}^{2}$ e a ilha IL2 com área de $0,026 \mathrm{~km}^{2}$ (Tabela 1 ; Figuras 8 e 9). A dinâmica intensa (desaparecimento e surgimento) está relacionada à dinâmica fluvial (erosão e sedimentação), à flutuação do lençol freático na planície e à atividade humana (desmatamento e retirada de barro).

A dinâmica de desaparecimento e surgimento das feições pode estar relacionada aos processos de erosão, transporte e deposição de sedimentação no corredor fluvial. Bayer E Carvalho (2008 p.24) ressaltam que a "morfologia do canal numa planície aluvial pode mudar em grande variedade de formas devido à atuação conjunta dos processos de erosão e sedimentação".

Souza (2004) estudou a dinâmica das feições morfológicas e migração lateral do canal no rio Paraguai no período compreendido entre1975 e 2000, entre a cidade de Cáceres e a estação ecológica da ilha de Taiamã. A autora constatou que as análises temporais das feições morfológicas da planície demostraram várias mudanças ocorridas na área de estudo, tais como junção de baías e lagoas; aumento da largura de vazantes; surgimento ou desaparecimento de lagoas e baías; diminuição, ou aumento, no tamanho de lagoas e baías; transformação de braços de rios em baías; e surgimento de ilhas fluviais.

Segundo o PBHP3 (2014), é de suma importância estudos sobre condições em que se encontra a água subterrânea e a posição do nível freático e suas variações. Esse levantamento é indispensável aos estudos hidrológicos para analisar quais os fatores proporcionam a recarga e a descarga do sistema subterrâneo e sua influência no nível freático.

Segundo Souza (2004), o estágio evolutivo que acontece no corredor fluvial (calha e planície) retrata as mudanças que 
ocorrem no sistema fluvial, em várias escalas temporais, associado à evolução geológica e climática da região e as interferências exercidas direta e indiretamente no canal pela atividade humana. Stevaux E Latrubesse (2017, p.239) também ressaltam que a "própria intervenção antrópica dos últimos milênios deve ser considerada na avaliação das causas das mudanças de um sistema fluvial".

Figura 8: Feições morfológicas 1984 (compartimento ll).

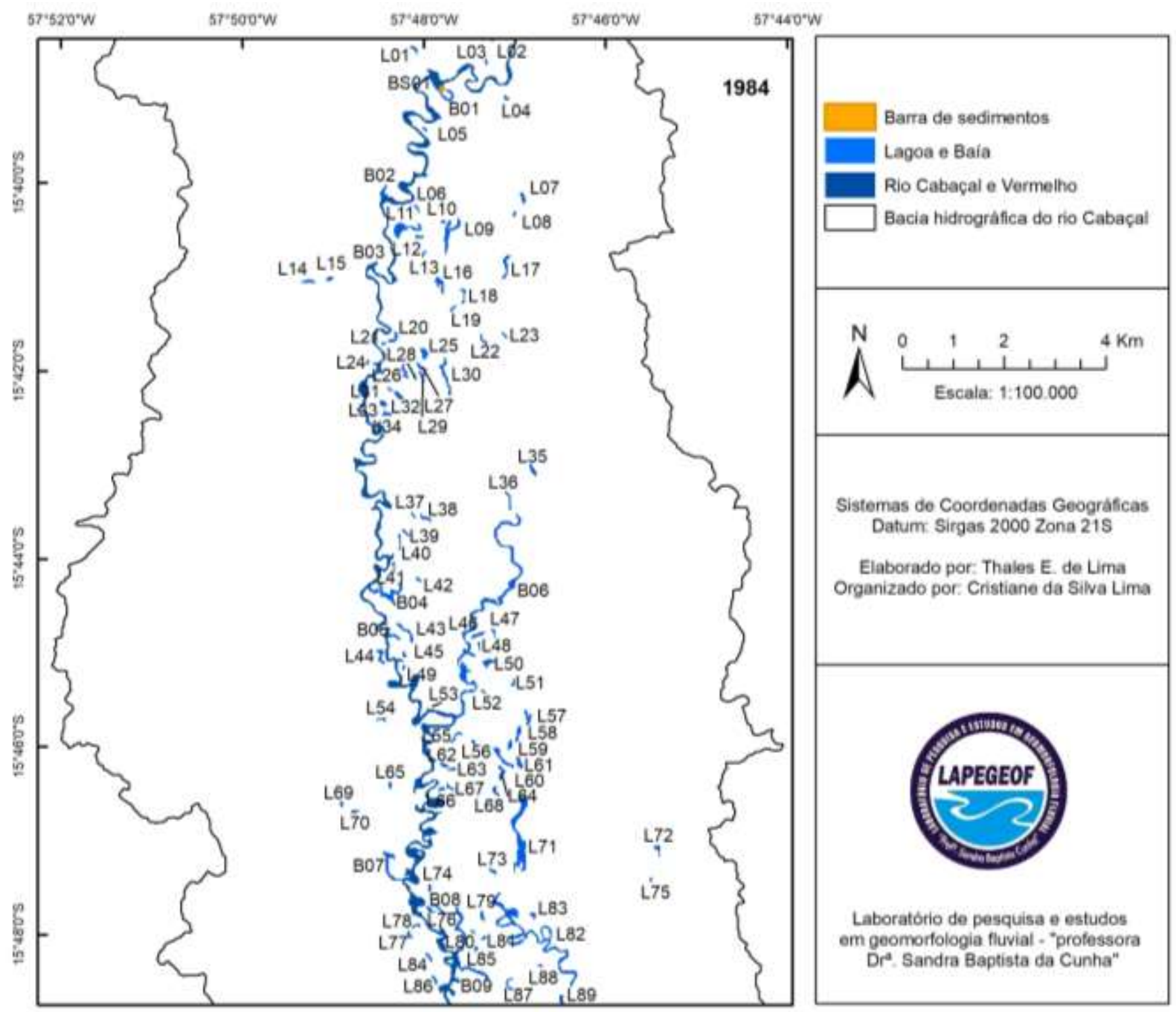

Fonte: Autores. 
Figura 9: Feições morfológicas 2018 (compartimento 11).

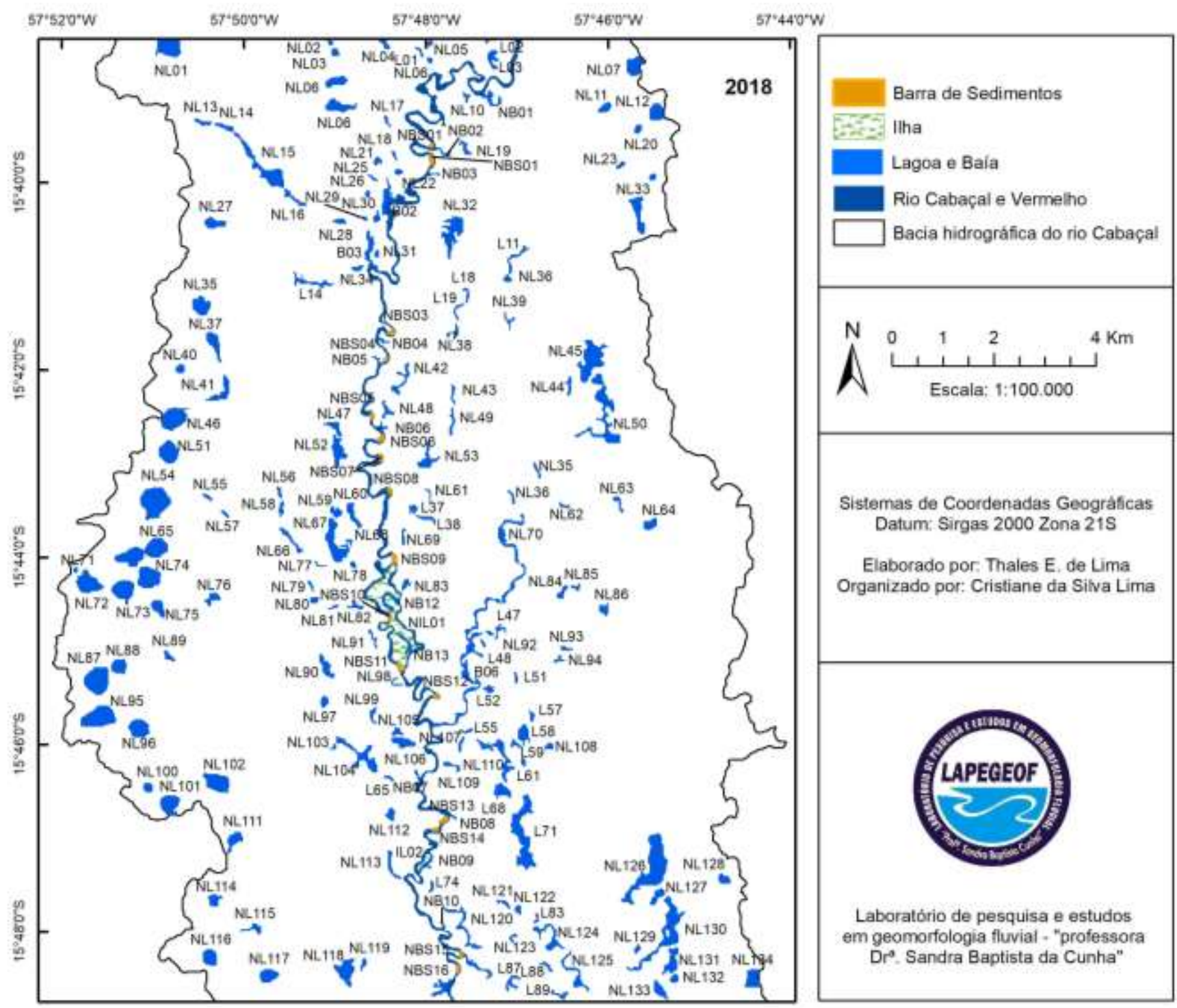

Fonte: Autores.

No compartimento III, em 1984, constatou-se a existência de 30 baías, 189 lagoas e 2 barras de sedimentos. Em 2018, teve como remanescentes seis baías e 68 lagoas. Novas feições surgiram na área, sendo: 13 baías, 138 lagoas, 23 barras de sedimentos e três ilhas fluviais, totalizando a área das três ilhas $8.813 \mathrm{~km} 2$ (Tabela 1; Figuras 10 e 11).

A partir do mapeamento realizado entre 1984 e 2018, constataram-se mudanças expressivas nesse compartimento, principalmente pelo aparecimento e desaparecimento de lagoas. Essas alterações podem estar relacionadas à própria dinâmica fluvial do rio Cabaçal; à contracorrente e transbordamento do rio Paraguai, pelo fato desse compartimento estar próximo da confluência dos rios Cabaçal e Sepotuba; ao rebaixamento de alguns setores na planície de inundação e pela oscilação do lençol freático (nascentes difusas).

Para Valente e Gomes (2005), esse tipo de nascente ocorre por pequenos vazamentos superficiais que se espalham por uma área meio encharcada (brejo) e esse processo vai acumulando água (poças). Calheiros et al., (2004) descrevem que podem originar nascentes com acúmulo inicial de água devido à camada impermeável encontrar-se paralela com a parte mais baixa do terreno e, ao ficar próxima com a superfície, acaba formando lagos. 
Alguns estudos classificam esse compartimento como pantanal do Cabaçal. Assine (2010) ressalta que o pantanal mato-grossense corresponde à parte central da depressão do alto Paraguai, o qual não é considerado como uma planície homogênea. Segundo esse estudioso, foram confirmados vários pantanais com características próprias de morfologia e dinâmica de inundação, os quais correspondem a diferentes sistemas deposicionais coordenados por sedimentação aluvial. A planície do rio Paraguai é responsável por receber águas de vários megaleques fluviais, produzidos por rios que têm suas nascentes nos planaltos presentes no contorno da depressão do Alto Paraguai.

O rio Cabaçal é considerado uma das sub-bacias do Alto Paraguai e Assine (2010) relatou que a oscilação do lençol freático regional é controlada pela planície do rio Paraguai; logo, evidencia-se a hipótese de surgimento de nascentes difusas no baixo curso do rio Cabaçal. Do mesmo modo, Zanin et al., (2013) afirmam que lagoas de planície tendem a ser perenes em períodos de escassez hídrica devido ao relevo ser considerado como fator determinante.

Para Riconimi et al., (2009), a ampla variedade que ocorre nos processos é responsável pela formação de lagos, influencia em diferentes morfologias, que vai desde lagos com centenas de metros quadrados em planície de inundação de rios. Os autores ressaltam que o balanço hídrico, precipitação e evaporação interferem na flutuação da lâmina de água dentro do lago.

Figura 10: Feições morfológica 1984 (compartimento 1lI).

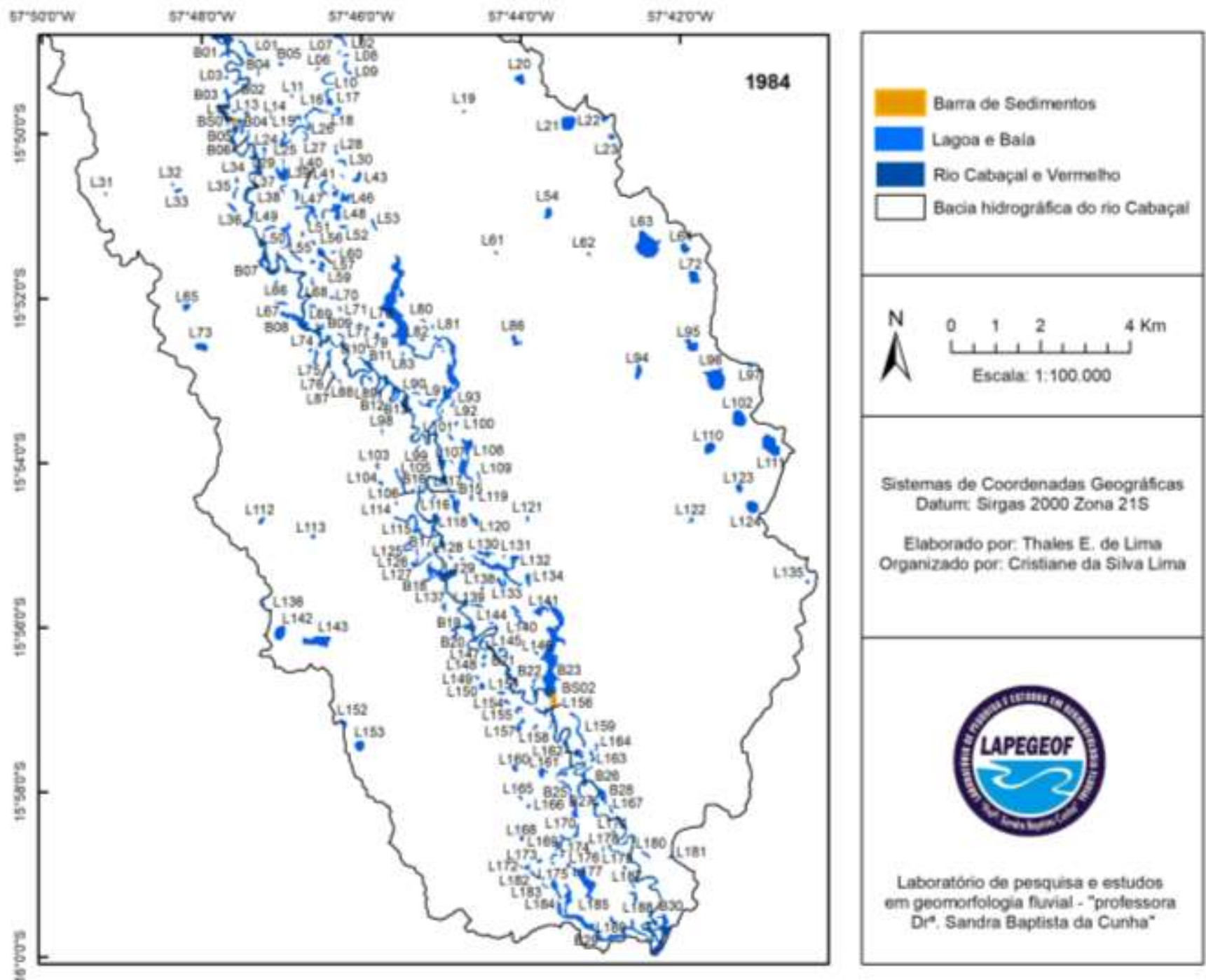

Fonte: Autores. 
Figura 11: Feições morfológica 2018 (compartimento 11I).
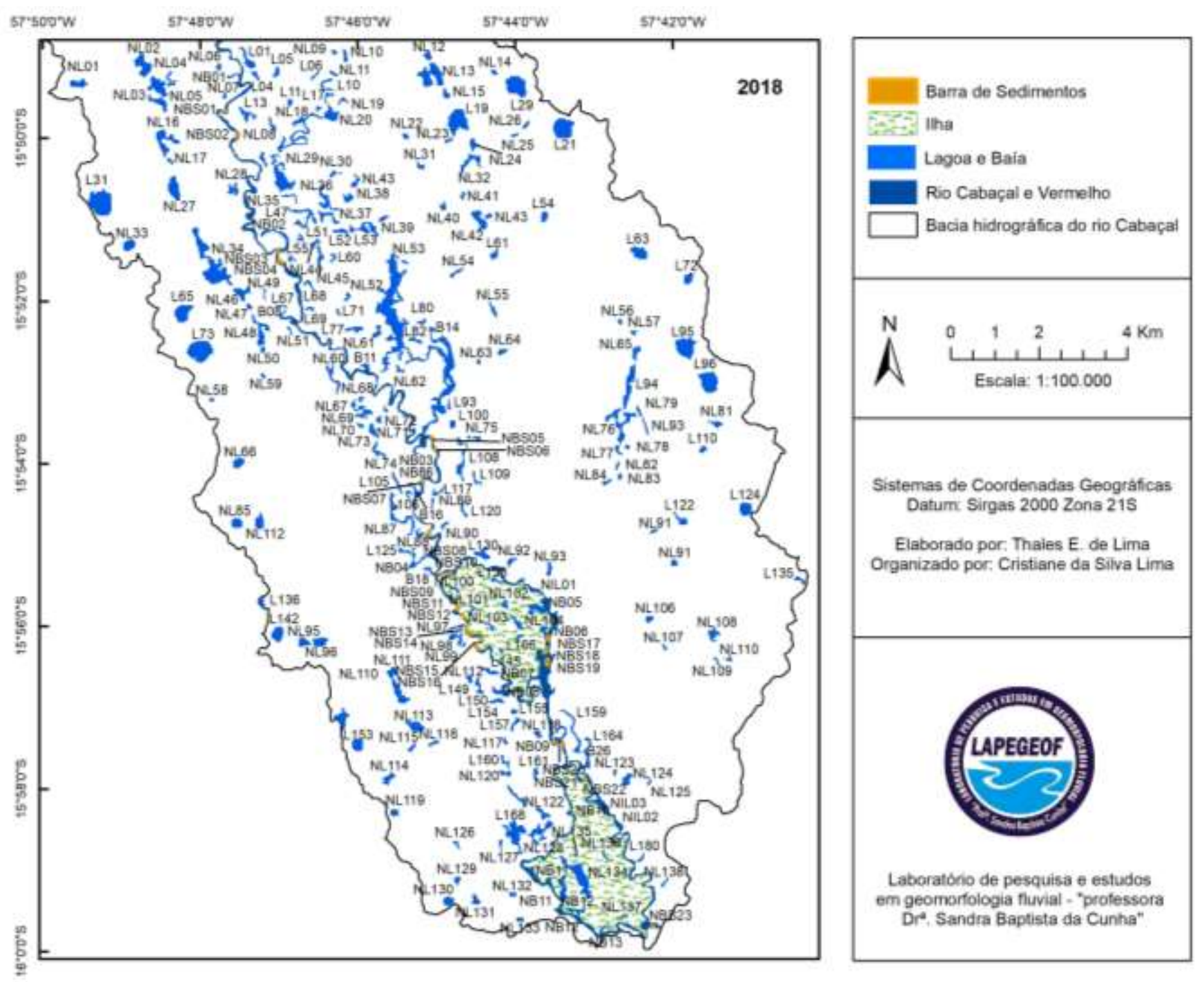

Fonte: Autores.

A dinâmica do baixo curso do rio Cabaçal em 34 anos, através do mapeamento, constatou que, em 1984, existiam 57 baías, 345 lagoas e 13 barras de sedimentos. Em 2018, as feições remanescentes foram 14 baías, 122 lagoas e uma barra de sedimento. Novas feições foram diagnosticadas no mapeamento de 2018, sendo: 47 novas baías, 380 lagoas, sete ilhas fluviais e 49 barras de sedimentos.

Estudos realizados por Prudêncio et al., (2017) sobre feições morfológicas no baixo curso do rio Sepotuba, entre a fazenda Porto do Campo e a fazenda Ajusta Conta, analisaram as alterações espaço-temporal (1986 a 2016) e registraram que, no período de 30 anos, várias modificações foram constatadas na cobertura vegetal, para introduzir a pastagem, aparecimento e desaparecimentos de feições. Os dados demonstraram que, em 1986, a área tinha 18 lagoas, enquanto que, em 2016, registrouse o desaparecimento de 9 lagoas e constatou-se o surgimento de 13 novas lagoas.

A soma das 13 barras de sedimentos mapeadas no ano de 1984 registrou área total de $0,063 \mathrm{~km}^{2}$ (Comp. I: 0,028 km², Comp. II: 0,021 km² e Comp. III: 0,014 km²), enquanto que, em 2018, o mapeamento classificou 50 barras deposicionais, totalizando área de 0,111 km² (Comp. I: 0,023 km², Comp. II: 0,043 e Comp. III: 0,045 km²).

O rio Cabaçal, no trecho estudado, está sofrendo um processo intenso de sedimentação, podendo estar relacionado à litologia da bacia, à ocorrência de solos e associado ao uso da terra (pecuária e agricultura), além da própria dinâmica fluvial 
por tratar-se de padrão meandrante.

Junior et al., (2017) estudaram as feições morfológicas entre a baía do Russo e a foz do rio Cabaçal entre os anos de 1986 e 2016, mostrando que, em 1986, havia seis baías, sendo a maior delas com área de 0,360 km² e a menor com área de 0,02694 $\mathrm{km}^{2}$. Registraram também 22 lagoas, a maior com área $0,112 \mathrm{~km}^{2}$ e a menor com área de $0,003 \mathrm{~km}^{2}$ e também a presença de um canal secundário com área de $0,729 \mathrm{~km}^{2}$. Em 2016, verificaram-se seis baías remanescentes, sendo que oito lagoas desapareceram e foram constatadas alterações na dimensão das feições (lagoas e baías). Houve o surgimento, ainda em 2016, de uma baía e 15 novas lagoas.

As lagoas identificadas no mapeamento, e in loco, a cada ano, aumentam sua área, há situações de junção de duas lagoas no período da cheia, quando o nível de água aumenta, chegando a trasbordar. Há casos também de inundação em pontos na MT-170. A origem dessas lagoas está associada à interferência antrópica, como retirada de solo para a construção da MT170, remoção de argila para abastecer as olarias e construção de represa para o gado beber água (Figura 12).

Figura 12: A) Lagoas Antropogênicas obtidas do google Earth (25/06/2017). B) Trasbordamento de lagoas antropogênicas na MT-170.

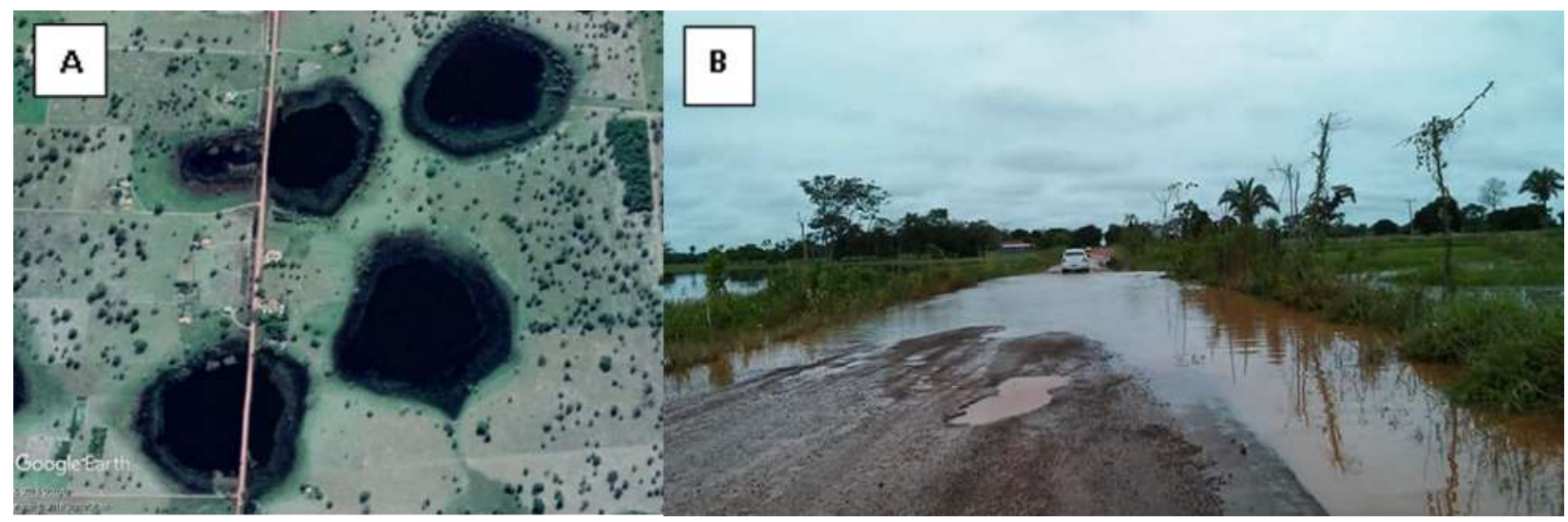

Fonte: Imagens cedidas por Cristiane Satin (23/02/2016) das lagoas na MT-170.

Parte das lagoas que estão espalhadas pelas planícies é resultado de construção de lagos "antropogênicos". Ricomini et al. (2010) fazem diferentes classificações de tipos de lagos e suas origens e relatam que os lagos antropogênicos são originados por construção de represa e escavação humana. Esse fato relaciona-se à hipótese de que a oscilação do lençol freático tenha contribuído para o surgimento de 380 novas lagoas no baixo curso da bacia do rio Cabaçal, fato que pode estar relacionado à oscilação do lençol freático, propiciando o surgimento de olhos de água nas áreas mais rebaixadas. Por fazer parte da planície do rio Paraguai, a área com uma grande quantidade de lagoas está entre o divisor de águas da bacia do Padre Inácio e a bacia do rio Cabaçal; lagoas que podem ser nascentes que afloraram devido à proximidade do lençol freático.

A retirada da vegetação em planície de inundação ou sujeita à inundação, provoca a subida do lençol freático, contribuindo para os surgimentos de lagoas. Estudos realizados por Sakamoto et al., (2012), com tradagens de topossequência em áreas preservadas e desmatada, identificaram alterações pedomorfológicas em cada ambiente, relatando que, em áreas preservadas, o perfil encontra-se em equilíbrio, enquanto que a área desmatada apontou desorganização pedomorfológica e o nível freático apresentou alteração estando mais próximo à superfície. Relataram também que análise integrada da paisagem contribuiu para a interpretação das alterações, influenciadas pela ação antrópica devido ao desmatamento.

\section{Conclusão}

O foco da pesquisa era verificar em escala temporal as mudanças morfológicas no baixo curso do rio Cabaçal, 
associando essas alterações aos aspectos ambientais (geologia, geomorfologia, clima, tipos de solos e vegetação) e ao processo de ocupação e os tipos de uso da terra.

Quanto aos aspectos geológicos, registrou-se a ocorrência de Formação Pantanal, aluviões atuais e aluviões indiferenciadas ou antigas. O levantamento da geologia local colabora para o entendimento da influência dessas ocorrências na evolução das feições morfológicas e no processo de sedimentação. A geomorfologia contribui para migração lateral e surgimento de feições, considerando que 33,77\% da planície e pantanais mato-grossenses (Planície do Cabaçal), as áreas embaciadas contribuem para formação de baías e lagoas.

A precipitação média anual é de 1.600 a $1.800 \mathrm{~mm}$ com deficiência hídrica moderada de 250 a $300 \mathrm{~mm}$ nos meses de seca (maio a setembro). No período chuvoso, o fluxo o rio Cabaçal coopera para ocorrência de erosão fluvial e no transporte de carga de sedimentos; porém, no período de estiagem esse material é depositado na calha e na planície de inundação.

As classes de solos predominantes no baixo curso da bacia hidrográfica são os Neossolos Quartzarênicos órtico tipico, Latossolo Vermelho Amarelo Distrófico Típico e Gleissolo Haplico Tb Eutrofico Típico, as mudanças morfológicas foram registras principalmente nos locais de ocorrência de Gleissolo Haplico Tb Eutrofico Típico, pela proximidade do rio e pelas próprias características (química e física) com encharcamentos periódicos ou constantes. A vegetação possui um papel importante na estabilidade das margens e no abastecimento do lençol freático e sua ausência contribui para oscilação do lençol freático e surgimento de lagoas.

O estudo permitiu observar a configuração espacial das feições morfológicas do baixo curso da bacia hidrográfica do rio Paraguai, sendo composto por alguns tipos de feições: lagoas, baías, depósitos de canais depósitos de margens de canais e depósitos de planícies de inundação, incluindo também a geração de informações espaço/temporais sobre o surgimento ou desaparecimento, redução ou aumento de dimensão de lagoas, baías, barras de sedimentos, ilhas fluviais.

Alguns elementos podem ter contribuído para alteração espaço/temporal das feições morfológicas no decorrer de 34 anos, como a dinâmica natural, interferência antrópica (desmatamento), a baixa declividade do terreno, rebaixamento de alguns setores na planície de inundação, a oscilação do lençol freático (nascentes difusas) e os aspectos climáticos, geológico, geomorfológico e os tipos de solo.

A pesar das contribuições exposta neste trabalho, a muito o que se fazer nesta mesma área de estudo. Deste modo, sugere-se estudos voltadas aos terraços fluviais e hidrodinâmica, a compreender o fluxo natural e antrópico da migração do canal que está ocorrendo no baixo curso da bacia do Cabaçal. Há ainda mais a se fazer, a exemplo, aferir a qualidade da água na baía da Onça, que possui grande importância aos sitiantes residentes da margem do rio Cabaçal neste trecho, e compreender o quanto de impacto ambiental a dragagem ali presente causa no ecossistema local.

\section{Referências}

Almeida, F. F. M. (1964). Geologia do centro-oeste mato-grossense. Boletim da Divisão de Geologia e Mineralogia. 1-133.

Assine, M. L. (2010). Pantanal mato-grossense: uma paisagem de exceção. In: Modenesi-Gauttieri, M. C et al., A obra de Aziz Nacib Ab’Saber. Beca-BALL edições, 464-489.

Avelino, P. H. M. (2006). Análise geo-ambiental multitemporal para fins de planejamento ambiental: um exemplo aplicado à Bacia Hidrográfica do Rio Cabaçal, Mato Grosso, Brasil. 2006. 323f. Tese (Doutorado em Geografia) - Programa de Pós-Graduação em Geografia. Universidade Federal do Rio de Janeiro.

Batista, M. de A., Paiva, D. W. \& Marcolino, A. (Org.). (2014). Solos para todos: perguntas e respostas. Embrapa Solos. 87 p. (Embrapa Solos. Documentos, 169).

Bayer, M. \& Carvalho, T. M. (2008). Processos morfológicos e sedimentos no canal do rio Araguaia. Revista de Estudos Ambientais, 10(2), 24-31.

Brigante, J. E. \& Espindola, E. L. G. (2003). Limologia fluvial: um estudo no rio Mogi-Guaçu, São Carlos: RiMa.

Calheiros, R. O. et al., (2004). Preservação e recuperação de nascente/ Piracicaba: Comitê das Bacias Hidrográficas dos Rios PCJ-CTR. 
Castro, W. S., Decampos, A. B. \& Zancopé, M. H. C. (2014). Migração do canal na planície fluvial do rio Claro-bacia do rio Araguaia, Goiás, Brasil. Revista Geonorte, edição especial, 4, 343-349.

Fernandez, O. V. Q. (1990). Mudanças no canal fluvial do Rio Paraná e processos de erosão nas margens: região de Porto Rico, PR. 1990. 85 f. Dissertação (Mestrado em Geografia), Instituto de Geociências e Ciências Naturais, UNESP, Rio Claro.

Goswami, U., Sarma, J. N. \& Patgiri, A. D. (1999). River channel changes of the subansiri in Assam, India. Geomorphology, 30, $227-244$.

Guerra, A. J. T \& Cunha, S. B. (Org.). (2004). Geomorfologia e meio ambiente. (5a ed.) Bertrand Brasil.

Hooke, J. M. (1979). An analysis of the processes of river bank erosion. Journal of Hydrology, 4(1-2), 39-62.

Junior, S. S., Souza. C, A., Prudêncio, V, S. \& Lima, T. E.; (2017). Feições morfológicas entre a baía do russo e a foz do rio Cabaçal, sudoeste de mato grosso. DOI: 10.20396/sbgfa. v1i2017.2142 - ISBN 978-85-85369-16-3. E-book Os desafios da geografia física na fronteira dos conhecimentos. 1005-1009.

Justiniano L. A. (2010). Dinâmica fluvial do rio Paraguai entre a foz do Sepotuba e a foz do Cabaçal. 72 f. 2010. Dissertação (Mestrado em Ciências Ambientais) - Instituto de Ciências Naturais e Tecnológicas, Universidade do Estado de Mato Grosso, UNEMAT, Cáceres, MT.

Leandro, G. R. S \& Souza, C. A. (2012). Feição morfológica no corredor fluvial do rio Paraguai, Cáceres, Mato Grosso: aporte de sedimentos na baía Negra. In: IX Simpósio Nacional de Geomorfologia, 2012, Rio de Janeiro, RJ. IX SINAGEO, Geomorfologia e eventos catastróficos: passado, presente e futuro.

Oliveira, V. A., Amaral Filho, Z. P. \& Vieira, P. C. (1982). Pedologia: levantamento exploratório de solos. In: Brasil. Ministério das Minas e Energia. Projeto RADAMBRASIL Folha SD, 257-400.

PBHP3- Plano da Bacia Hidrográfica do Paraná 3. (2014). Monitoramento dos recursos hídricos. Universidade Estadual do Oeste do Paraná Itaipu Binacional águas Paraná. Comitê da Bacia Hidrográfica do Paraná 3.

PCBAP. (1997). Plano de Conservação da Bacia do Alto Paraguai/ Projeto Pantanal. Programa Nacional do Meio Ambiente, PNMA.

Prudêncio, V. S., Souza, C. A. \& Paula, W. C. D. S. D. (2017). Transporte de sedimentos em suspensão e feições morfológicas no baixo curso do rio Sepotuba entre a fazenda Porto do Campo e a fazenda Ajusta Conta. In: $8^{a}$ Jornada Científica da Unemat, 8 a . (JC), 2017, Cáceres/MT. Anais... Cáceres/MT: Pró-Reitoria de Pesquisa e Pós Graduação, Pró-Reitoria de Ensino de Graduação, Pró-Reitoria de Extensão e Cultura e Pró-Reitoria de Assuntos Estudantis. v. 8.

Riccomini, C. et. al., (2009). Processos fluviais e lacustres e seus registros. In: Teixeira, W et al., (2009). Decifrando a Terra. Companhia Editora Nacional.

Ross, J. L. S., \& Santos, L. M. (1982). Geomorfologia. BRASIL. Ministério das Minas e Energia. Projeto RADAMBRASIL Folha SD, p. $193-256$.

Ross, J. L. S., \& Santos, L. M. (1982). In: RADAMBRASIL: levantamentos dos recursos naturais. Cuiabá, Rio de Janeiro: Ministério das Minas e Energia. Secretária Geral. Projeto RADAMBRASIL. Folha SD 21, 448 p.

Sakamoto, A. Y. et al., (2012). Desmatamento e alterações ambientais no Pantanal da Nhecolândia, MS, Brasil. Revista Geonorte, Edição Especial, 3(4), 827839.

Santos, E. L. F. (2011). Educação ambiental nas nascentes do Pantanal no município de Reserva do Cabaçal, MT. 2011. Dissertação (Mestrado em Ciências Ambientais) - Programa de Pós-Graduação em Ciências Ambientais, Universidade do Estado de Mato Grosso, UNEMAT, Cáceres, MT.

SEPLAG- Secretaria de Estado de Planejamento e Gestão. (2011). Atlas de Mato Grosso: abordagem socioeconômico-ecológica. Entrelinhas.

Silva, E. S. F. et. al., (2013). Evolução das feições morfológicas do Rio Paraguai no Pantanal de Cáceres, Mato Grosso. Revista brasileira de geomorfologia. 13(4).

Silva, E. S. F. (2011). Dinâmica fluvial do rio Paraguai entre Furado do Touro e Passagem Velha do Pantanal Mato-grossense no município de Cáceres - Mato Grosso. 79 f. Dissertação (Mestrado em Ciências Ambientais), Programa de Pós-Graduação em Ciências Ambientais, Universidade do Estado de Mato Grosso. Cáceres, MT.

Silva, E. S. F. et. al., (2014). Caracterização ambiental e morfologia do Rio Paraguai entre a foz do rio Jauru e a ilha Tucum, Cáceres - Mato Grosso. Revista Geonorte, Edição Especial 4, 10(1), 217-222.

Silva, M. D. \& Farias, E. S. O. (2007). Relevo como fator controlador da paisagem aplicado ao estudo de unidades ambientais homogêneas em sistemas naturais ocupados por empreendimento florestais de grande porte no Sul do Rio Grande do Sul, Brasil. Anais... do VIII Congresso de Ecologia do Brasil, Caxambu - MG, 23 a 28 de setembro de 2007.

Souza, C. A. (Org.). (2012). Bacia hidrográfica do rio Paraguai, MT: dinâmica das águas, uso e ocupação e degradação ambiental. São Carlos: Editora Cubo. Souza, C. A. (1998). Bacia hidrográfica do córrego Piraputanga, MT: avaliação da dinâmica atual. 1998. 117f. Dissertação (Mestrado em Geografia). Universidade Federal do Rio de Janeiro.

Souza, C. A. (2004). Dinâmica do corredor fluvial do rio Paraguai entre a cidade de Cáceres e a Estação Ecológica da ilha de Taiamã, MT. 2004. 173f. Tese (Doutorado em Geografia). Centro de Ciências Matemáticas e da Natureza, Universidade Federal do Rio de Janeiro, UFRJ.

Souza, C. A. \& Cunha, S. B. (2007). Pantanal de Cáceres, MT: Dinâmica das Margens do Rio Paraguai entre a Cidade de Cáceres e a Estação Ecológica da Ilha de Taiamã, MT. REAGB - Seção Três Lagoas, 1(5), 18-43.

Souza, C. A.; Sousa, J. B.; \& Silva, L. N. P. Bacia hidrográfica do rio Jauru e seus afluentes. Enciclopédia Biosfera, 10, 611-635, 2014. <https://conhecer.org.br/ojs/index.php/biosfera/article/view/2691>.

Stevaux, J. C. \& Latrubesse, E. M. (2017). Geomorfologia fluvial; Oficinas de textos, coleção geografia; v.3/. FRANCISCO A. M. (Org.). 
Research, Society and Development, v. 10, n. 12, e109101220226, 2021

(CC BY 4.0) | ISSN 2525-3409 | DOI: http://dx.doi.org/10.33448/rsd-v10i12.20226

Valente, O. F \& Gomes, M. A. (2005). Conservação de nascentes: hidrologia e manejo de bacias hidrográficas de cabeceiras. Aprenda Fácil.

Zanin, P. R., Bonumá, N. B. \& Chaffe, P. L. B. (2013). Características hidrogeológias de nascentes situadas em diferentes modelados de relevo. XX Simpósio Brasileiro de Recursos Hídricos. ABRH. 